821.163.41-2.09

https://doi.org/10.18485/msc.2018.47.2.ch30

\author{
Миливоје В. МЛАЂЕНОВИЋ* \\ Универзитет у Новом Саду \\ Педагошки факултет Сомбор
}

Оригинални научни рад

Примљен: 31. 11. 2017.

Прихваћен: 27. 12. 2017.

\title{
ВИДОВИ КАРНЕВАЛИЗАЦИЈЕ У КОНЦЕПЦИЈИ ДРАМСКОГ ЛИКА ЛАЗЕ КОСТИЋА
}

\begin{abstract}
Драме о Лази Костићу (Ното volans Н. Прокића, Камо ноћи, камо дани Р. Дорића, нарочито, а у извесној мери и Pancoduja В. Б. Поповића, Santa Maria della Salute V. Lukića као и рестаурација трагедије Максим Црнојевић коју је урадио Слободан Стојановић), настале употребом, преобликовањем, међутекстовним надовезивањем, деструкцијско-субверзивним поступањем према претходним текстовима, у основи садрже одлике карневализације као књижевног поступка. Видови карневализације у концепцији драмског лика Лазе Костића у овом раду анализирају се, пре свега, у појавама гротескно-карикатуралне асоцијативности. Лик Лазе Костића је у појединим драмским секвенцама приказан у складу са сликом карневалског система: космичко, социјално и телесно приказани су као недељива, жива целина. Обриси карневализације потом се уочавају и у начелу његовог укрштаја - врхунског склада који потиче из врхунског расклада, у жудњи за материјализацијом нематеријалних сензација, „еротском космизму” пониклом из укрштаја са ништавилом, еротизму који избија из Костићевог дневника, итд. Појаве карневалског доживљавања света идентификују се и у сликама Костићевог распусног, театралног живота, као и у редукованим облицима - сарказму, иронији и сатири, подсмеху здраворазумског грађанина и позитивиста српске књижевне критике романтичарском „женију”.
\end{abstract}

Кључне речи: Лаза Костић, карневализација, драма, гротеска, иронија.

Драмска књижевност нашег века ослања се на редуковану карневалску традицију. Такво поступање видљиво је и у драмским делима која су настала на основу биографије Лазе Костића. Драме у чијем је средишту лик Лазе Костића могуће је везати уз раблеовску традицију и народну културу, па их разматрати у светлу Бахтинове теорије карневализације. Одређеније речено, може се утврдити поступак непрестаног и континуираног превођења облика карневалског фолклора у карневализоване облике књижевности, могу да се означе главни преносиоци карневалског осећања света у овим драмским делима. ${ }^{1}$

"milivoje_mladjenovic@yahoo.com

1 Дела Лазе Костића такође садрже елементе карневализације. Песма „Дон Кихоту” садржи мотиве и ликове (као што је типски лик луде, материјално-телесно начело) који су типична ознака карневалске атмосфере: 
У Камо ноћи, камо дани радња драме има све елементе представљачког, многи догађаји су „представа” за Лазу Костића уочи његовог одласка на лечење у Беч: омладина му пише песме, говори беседе у српској читаоници, сомборске госпође приређују „жур” у његову част. И симпозијуми, празничне гозбе, прославе рођендана и слични догађаји у драмским делима Homo volans Ненада Прокића и Pancoдија Владимира Б. Поповића јесу облици празничног, карневалског. У Камо ноћи, камо дани најизразитији је тај наслеђени „карневалски осећај света”, читљив и у тежњи да се избрише граница између учесника и посматрача. Сви су истовремено и у једној и другој улози: Лаза Костић је посматрач суграђана који му припремају испраћај, а истовремено они посматрају Лазу Костића који за њих „изводи” своју представу, у којој глуми затеченост приређеним „перформансом” у његову част.

У спољашњој манифестацији Лазе Костића неретко се иде и до елемената гротеске која је, према Бахтину такође дериват маске: „Треба истаћи да такве појаве као што су пародија, карикатура, гримаса, кревељења, пренемагања и томе слично представљају у својој суштини деривате маске. У маски су веома снажно открива сама суштине гротеске" (Бахтин 1978: 49). Отуда се може говорити и о карневалескној природи појаве Лазе Костића [...] Бахтин нас опомиње да је народна карневалска природа маске у романтичарској гротески неуништива. „Маска је чак и у условима обичног савременог живота увек обавијена неком посебном атмосфером, прихвата се као делић неког другог света. Маска никад не може постати једноставно ствар међу другим стварима (Бахтин 1978: 50)" (Млађеновић 2017: 133).

Прва слика ове пригодне драме 2 подсећа на припрему неке врсте карневалске светковине у којој песник управо указује на карневализовану блискост смрти и рађања:

GRADONAČELNIK: Ceo se grad...kako da kažem...pretvorio u svečani odbor, za vaš ispraćaj u Beč.

„у жестини окршаја

ветрењача многа звечи,

кад је глави друго место,

а трбух се за све брине:

сећањем те се врло често,

будалине Севедрине" (Костић 1989: 300).

Расправа $O$ народном глумовању (1893) дотиче се подручја карневализације у описима народних обичаја „чини ми се да је у коледама, краљицама, ладалицама и додолама исти замет што га испитивачи старина налазе за јелинску драму” (Костић 1989: 340). У рестаурацији његове трагедије Максим Црнојевић у уметнутим, дописаним сценама, најдиректније се приказује вртлог карневалских збивања у Венецији. И адаптација његове комедије Гордана садржи одлике карневалског. Те појаве остају ван овог разматрања јер је рад тематски сужен на концепцију лика Лазе Костића у драми.

${ }^{2}$ „Настанак програма Камо ноћи, камо дани, који је по свом формалном устројству „класична" представа, инициран предлогом КПЗ Србије да 1991. године, Народно позориште из Сомбора припреми и изведе драмски програм на завршној свечаности манифестације Вуков сабор у Тршићу код Лознице. Повод је био јубилеј - 150 година од рођења Лазе Костића" (Млађеновић 2016: 95). Сам карактер ове уметничке изведбе, њено устројство као друштвеног догађаја, има, сасвим извесно, формалне одлике карневалског: то је јавни догађај на отвореној позорници који има „посебну друштвену сврху и функцију” (Јовановић 2015: 141), те се може детерминисати као метакарневалска творевина. 
$[\ldots]$

LAZA: Dakle, nisam umro...I nisu me zaboravili...

DOKTOR: Pa, pre bi se moglo reći da si se ponovo rodio.

LAZA: Ponovo rodio? Ali samo je jedna smrt i jedno je rođenje (Дорић 1991: 7).

У истој сцени, Лаза Костић поредећи свој долазак на свет са часом рођења великог немачког песника Гетеа, говори о укрштању противности и крајности које такође припада подручју идеологије карневала:

Možda mi je i zato bilo suđeno da provedem svoj vek u borbi, posred raznih protivnosti i krajnosti, u neprestanom otimanju, i večnom ukrštaju; i da budem ispitivač i propovedenik toga načela (Дорић 1991: 8).

На сличном принципу изграђен је и Homo volans Ненада Прокића. Разлика је само у томе што је карневалски извор знатно удаљенији. Атмосфера симпозијума, која је подлога Прокићеве драме, јесте евокација карневалске гозбе.

Književnost nakon Rablea bila je svakako bogatija za mogućnost vlastite karnevalizacije i prigrlila je scene gozbe [...] Gozba je osobeni okvir u kome se jezik (govor, razgovor, dijalog, polifonija, heteroglosija, diskurzivni žanrovi) odvija i razvija nesmetano, bez cenzure i ograničavanja [...] mudra reč je mudra zato što nije autoritativna, upućena je sagovorniku, interpretira se i značenjski nadograđuje i ,filtrira” u dijalogu, na taj način otkriva se istina (Јовановић 2017: 145).

Типичан пример карневалског наслеђа је гозба у Костићевој кући у драми Homo volans Ненада Прокића, која укључује истовремено и карневализацијску полемичност, расправу о вредностима Костићеве поезије. Такав пример налазимо и у Рапсодији Владимира Б. Поповића.

Користећи се Гетеовим описом карневала, Бахтин закључује да карневал одликује специфична празничност без страхопоштовања, потпуно ослобађање од озбиљности, атмосфера једнакости, слободе и фамилијарности, смисао погледа на свет својствен непристојностима. Све те особености запажамо у драмама Камо ноћи, камо дани и Рапсодија, као и одблеске веселих карневалских ратова и туча каква је, на пример, туча у Рапсодији Владимира Б. Поповића.

У целини посматране, драме о Лази Костићу садрже и рефлекс менипејске сатире чија се обележја очитују најпре у формалном погледу - у мешању поезије и прозе: у цитирању, ,preosmišljavanju i parodiranju filozofskih sistema” (Силард 1984: 69), присуству комичног и смешног.

Menipejska satira, oblik (uglavnom prozne) satirične forme, pokazuje, pak, jasnije veze sa karnevalskim duhom. U ovoj književnoj formi situacije su često komične, zasnovane na mešanju fantastičnih, mističnih i religijskih elemenata sa „sirovim” naturalizmom scena iz kafana ili javnih kuća. Tematika menipeja je čas filozofska, a čas vulgarna; o velikim životnim pitanjima diskutuje se kroz estetski sasvim polarizovanu debatu (Јовановић 2015: 139).

Пример у драми Рапсодија показује да је предмет менипеје критика и пародија општих типова. Сцене, различито интониране смењују се великом брзином. 
SIMO: Vi ste našli da procenjujete ko je kakav pesnik, a ko kakav čovek! Duhovni invalidi! Intelektualno impotentne osobe! Vi ste, gospodine Popoviću preispoljna budala, koja zavidi celom svetu!

BOGDAN: Ja ovo ne mogu da trpim od jednog kvazipisca i pijandure i njegovog kompanjona prevaranta!

(Simo uhvati Bogdana za revere i podigne ga od stola, a potom ga odgurne. Zmaj pokušava da se umeša. Gosti zainteresovano posmatraju šta će se desiti. Aplaudiraju. Simo udara šamar Bogdanu. Laza tek nakon nekog vremena pogleda šta se dešava, ali ne prekida sa jelom.)

BOGDAN: Tražiću zadovoljenje!

SIMO: U svako doba!

BOGDAN: Ali na sudu. Pesnički šarlatani!

(Поповић 2017)

С обзиром на то да је карневал један облик народно-смеховне културе, и да сам Бахтин као основно начело карневала наводи смеховно, управо се од смеха и полази у анализи, смешан догађај заснован је на досетки: фактору изненађења које изазива инверзија мало-велико. То је, како би дефинисао Анри Бергсон, „rafiniranija transpozicija nižeg u više, koja se odnosi na vrednost stvari a ne više na njihovu veličinu" (Бергсон 1993: 61).

(Simo prilazi sakou. Podiže ga. Iz unutrašnjeg džepa vadi jedan list hartije i od njega otkine izuzetno mali komadić, gotovo milimetarske veličine. Prilazi Bogdanu koji se sklanja od Sime ode oko stola.)

ZMAJ: Pobogu, ljudi smo, nismo deca. Gospodine Matavulj, šta Vam sve ovo treba? Pa nismo došli zbog zle namere. A i Vi, Bogdane, ne umete da se kontrolišete. Obuzdajte taj Vaš jezik.

SIMO: Izvolite, nemušti prevodicu i kritizerski laiku. Napišite biografiju. (Pruža mu komadić hartije.)

ZMAJ: Prestanite!

(Laza završava sa večerom. Briše se salvetom.)

LAZA: Čado, šta se uzbuđuješ.

Popović je Bogdan pisac dara retka,

Napis'o je do sad četiri početka.

(Kafanom se prolomi smeh. Simo stavlja sako na naslon stolice. Seda za sto. Bogdan popravlja svoj sako. Žurno izlazi iz kafanske bašte.) (Поповић 2017).

Основне одлике празничног смеха према Бахтину су општенародност, универзалност, као и амбивалентност, која представља срж филозофије карневала. У току трајања карневала, као што је већ поменуто, владају посебна правила и закони. Долази до инверзије улога, свет је окренут наглавачке. У драми Homo volans Јаша Шашин „пандур за послугу” управља карневалом, у овој драми преиспитују се и владајуће критике о Лази Костићу. У Дорићевој драми Камо ноћи, камо дани уочава се другачији карневалски принцип: приметно је „укидање хијерархијских односа” стварање присних и фамилијарних односа међу људима. У Дорићевој драми сви ликови су присни са великим песником.

У карневалском свету све је амбивалентно, па је чак и смрт весела јер „gde je smrt, tu je i rađanje, smena, obnova” (Бахтин 1978: 426). О том карневалском односу према смрти говори и атмосфера у којој се евоцирају успомене на Лазу Костићу, у драми Homo volans. Давид, пријатељ песников, у посмртном часу, користи се средствима карневализације. Ту се манастирска благост и узвишена господственост јављају у споју са профаним, лакрдијашким: 
DAVID

Ma ja vam kažem da naš prijatelj i tamo gore pravi iste onakve kalambure [...] sad mi lepo njemu pomen da održimo - a onda za igumanskom trpezom ono pravo sećanje na njega da obnovimo.

GEDEON

Sarmu da sipamo u čaše i viljuškom supu da jedemo (Прокић 1986: 39).

Амбивалентност се потврђује и у сцени када два свештеника у порти манастира Крушедол препричавају како се „повише торња” појављује песник као „утвара”, што је асоцијација на свет горе и доле:

VELJKO

Kolaju priče da poviše Krušedola ne lete samo ptice i avioni...

JOVAN

Nego i pesnici, je li...?

BOGDAN

Načuo sam nešto o tome. Kaluđerske fantazije, pravoslavno ludilo! Ko to još, na samom kraju dvadesetog veka veruje u takva snoviđenja? (Прокић 1982: 3).

Индиректна евокација карневалске традиције манифестује се у Прокићевој драми Homo volans у сцени у којој Вељко жали што учесницима научног симпозијума, уместо уживања у осматрању летњег неба изнад манастира Крушедола, није предложено уживање у музици тамбураша и доброј трпези на Петроварадину, односно материјално-телесном. На ово телесно „кретање наниже”, како га Бахтин дефинише, на неумереност у храни, опомиње и Богдан:

BOGDAN

I kako je mogao da bude talentovan čovek koji je bio u stanju da toliko ždere? Alfred Brem bi Ga svakako metnuo u svoju čuvenu knjigu samo da je čuo za njega. Sa te svoje vrline, obično se nalazio po manastiri, jer tamo je često dobar kost (Прокић 1984: 5).

Карактеристично је да се овај исказ од речи до речи понавља и у Осмој слици (стр. 47), чиме се наглашавају црте карневалског у карактеру лика Лазе Костића. Чини то и Гедеон, потцртавајући управо ову особину песникову, и то у споју са узвишеним, песничким:

Samo polako, gospodo! Pričuvajte stomake. U njima mora ostati mesta za čitavu trpezu naše slavnog pesnika, dičnog rodoljuba i poštene duše - a ta trpeza, kao što znate, uopšte nije oskudna (Прокић 1984: 10).

$\mathrm{Na}$ амбивалентност у природи и уметничком деловању Лазе Костића упућује и Јован Скерлић (цитиран у драми Homo volans) који приписује песнику особине епигона европских романтичара који су „sa nogama na zemlji ali s glavom u oblacima”; високо се меша са ниским, земља с облацима. На особине карневалског Јован (мисли се на Скерлића) упућује још једном: „rukovao је kalamburima kao vašarski mađioničar oštrim noževima” (Прокић 1986: 46).

Трећа слика у драми Homo volans је у целини изграђена на карневалској традицији. Овде се, као у Раблеовом роману, користи семантичка баналност хране и пића, дугачким набрајењем гастрономских пикантерија и пића. „Пандур за послугу", Јаша Шашин, наводи садржај вечере код славног песника: 
JAŠA

Ajvar iz Kladova, morske ribe više vrsti, pečujsko vino, kasapski đuveč, pikantne ovčije krmenadle, čimbur s mesom, salata od divljači, pa jegulje u sosu od piva, palačinke u pari, štanglice kraljice Marije, ljubavna pisma, žerbo šnite i bele puslice. Jošte kafa i kajsijevača, pa šampanj vino s jagodama (Прокић 1986: 13-14).

У Прокићеву драму „проваљује” цитат из Стеријине Покондирене тикве. Исказ „Jesti i piti mon frer, jesti i piti, to je ljubov. Manite se vaših boginja i gracija, vila, satira i anđela" такође је карневализацијска ознака Стеријине облапорне Саре, која се овде сада преноси као књижевна традиција. Потом се у паратексту ауторовим дидаскалијама конкретизује „сеremonijal posluživanja i velikog ždranja” (Прокић 1986: 14) којим управља слуга:

Pije se po strogom sistemu - brzo i do kraja. Čim neko podigne čašu, kao po komandi svi ustanu uz uzvik i saspu sadržinu u grlo. Zatim sednu i nastave sa ždranjem. Posluga odmah puni čaše i sve to se mehanički ponavlja. Ritam se polagano usporava. Jaša Šašin oseti trenutak i pošalje poslugu van. U tišini, čuje se samo dahtanje, brektanje i stenjanje gospode koji su se prejeli [...] (Прокић 1986: 15).

Тумачећи процес карневализације у Бахтиновом одређењу, Лена Силард потцртава Бахтиново упозорење „da se treba osloboditi pojednostavljenog shvaćanja karnevala u duhu maskeradne linije novog vremena, a još više njezinoga banalnog poimanja na boemski nас̌in" (Силард 1984: 50). Управо у овој драмској слици се крије та опасност од поједностављивања, али ту гозбену слику, то „велико ждрање” ваља посматрати као метафору, као слику једног друштва, на којој видимо великог песника, час у опреци према маловарошком животу, час у мирењу са светским брлогом - целовитост профаног и узвишеног као принцип. Неумереност лика Лазе Костића одговара управо Бахтиновом концепту „Jedenje i pijenje su među najvažnijim ispoljavanjima života grotesknog tela. Telo dok jede, prevazilazi granice i to je svojevrstan susret čoveka sa svetom [...] predstavlja univerzalni princip spajanja čoveka sa kosmosom" (Ристивојевић 2009: 204).

Слика великог ждрања понавља се у седмој сцени, сада још уверљивије карневалска, раблеовска, јер су међу њеним учесницима и свештеници. Они су представници „старог света” с којим се ваља обрачунати, као у Гаргантуи и Пантагруелу:

У позадини, на манастирским одајама, осветли се један велики прозор. Оштре контуре Митрофана, Гедеона, Давида, Чордара и Радивоја са још неколико поповских обриса. Сви седе за столом и једу. Чим неко подигне чашу, као по команди сви устану и саспу садржину чаше у грло. Затим седну и наставе са ждрањем. То се механички понавља (Прокић 1986: 45)

Аутор додаје и сатирични коментар, у духу двадесетог века, упирући оштрицу колико према цркви толико и према научним круговима и њиховој склоности ка прекомерном уживању у плотским стварима: 
LJUBOMIR

A koji su vam ovi

MLAĐI SVEŠTENIK

Gospoda su arhimandritovi gosti.

STARIJI SVEŠTENIK

I rekao bih da imaju ponešto zajedničko sa vama.

BOGDAN

Sa nama?!

JOVAN

Mora da su i oni sa nekog simpozijuma.

(Прокић 1986: 45)

У четвртој слици запажен је еротизам, у духу узајамног прожимања супротности старо-младо. Сцена је кореографска, са израженим мотивом „materijalno-tjelesnog prizemlja” (Силард 1984: 54).

Pesniku prilazi Ballateta, stavi mu svoje šake preko očiju. Pesnik se bezuspešno otima sve dok Ballateta ne odluči sama da ga pusti da pogleda. Gledaju se. Ona počinje na prstima da se udaljava. On pruži ruke ka njoj (Прокић 1986: 18).

Песник потом говори стихове Езре Паунда, са карактеристичним стихом „паучина бабљег лета”, којим се наглашава гротескност призора остарелог песника и младе играчице:

Ballatetta počne da igra usporeni erotski ples oko pesnika. Uvija se, previja, njiše i grči. $\mathrm{Na}$ kraju padne na kolena pred njim. Ispruženu ruku upre ispod pesnikovog stomaka i ostavi je tamo da miruje (Прокић 1986: 18).

Евокација карневалске форме јавља се и најдиректнијој, гротескној форми, описана у дидаскалијама:

Uz gromoglasnu muziku u salon nagrnu vile, satiri, anđeli, gracije, boginje, amoreti i nimfe. Počne veličanstveni erotizovani karneval kojim upravlja ceremonijal majstor - Saša Jašin. On daje znake nenametljivim i elegantnim pokretima, pucketa prstima, koluta očima, diže obrvu, gleda čas strogo, čas se osmehuje, vile jašu satire, satiri su u koitusu sa nimfama. Gracije se ljube sa boginjama, anđeli grle amorete... Dolaze pred pesnika i izvode svoje veštine, pesnik takođe uzme učešća u plesu i trapavo skačući ruši po sobi, baca papire sa Schreibtischa i oni lete okolo. Onda se pojavi Ballatetta i sve zamre [...] (Прокић 1986: 35).

У Дорићевој драми Камо ноћи, камо дани у Трећој слици, чија је радња смештена у кафану и која већ по свом устројству, церемонијалу, социјалној улози припада сфери народне смеховне културе, могуће је утврдити обрисе карневалске традиције. То је уочљиво већ у песми којом Лазу дочекују његови пријатељи, бећарцу-каламбуру који је испеван, према анегдотама, на свадби Лазе Костића и Јулијане Паланачки:

„Biće kume moj kubure

Đokin trbuh kao bure

popiće taj nije šala

tokajera tri bokala

dinum, danum, šum, šum, šum"

(Дорић 1991: 21). 
Сцена асоцира на раблеовске слике гротескног пијанчења. Као и у Раблеовом роману Гаргантуа и Пантагруел и у овој Дорићевој драми, у гозбеној слици учествује свештено лице:

POP

Pa, eto i mene ste privarili pa me ovde dovukli. Svešteno lice, takoreći (Дорић 1991: 22).

Лаза Костић, тобоже, опомиње „организаторе” да им „ништа није свето”, јер каламбур певају недуго после смрти Јулијане Паланачки. Ђока Чордар, карневалски обликован лик, снижава значење озбиљног: crkva.

ĐOKA: A što smo te ovde zvali? Ne misliš valjda da je ovo Matica srpska il ne daj Bože (Дорић 1991: 21).

Снижавање озбиљног тона уочава се и у примедби Доктора (Симоновића):

Kolko je samo tvojih pesama i romana ovde ostalo, u vetar i sprdnju odletelo (Дорић 1991: 22)

\section{На исти начин реагује и Давид (Коњовић):}

[...] ova je kafana više živela od tvojih kalambura neg' od špricera! I nemoj mi samo kazati da si i ti sve što si napis'o, uzim'o ozbiljno.

LAZA: Ne d'o Bog!

(Дорић 1991: 23)

Пета слика садржи ублажену ласцивност, духовитост еротског садржаја, која је такође наслеђе карневалског духа:

III GOSPOĐA

Meni ste, jednom, davno, napisali...nešto, božem prosti moglo bi se razumeti i k'o bezobrazno pa bi molila, ako može štogod lepše čime bi se mogla faliti...

LAZA

Bezobrazno napisao? Gospo moja (gleda je, merka) biće da sam im’o razloga, a možda i povoda.

III GOSPOĐA (kikoće se, igra snebivanje, a uživa u ironičnim podtekstima)

Nema više stranica prednjica,

sav se narod na njima izređa

blago meni, kad ne mogoh s lica,

bar ću tebi prvi biti s leđa.

LAZA

Pa to je baš zgodno zamišljeno.

III GOSPOĐA (uzdahne) Ta, zamalo i da se ostvari!

LAZA: Ali, to je ipak samo igra.

(Дорић 1991: 41)

Занимљива је појава да у драми Santa Maria della Salute В. Лукића, Лаза Костић у разговору с Игуманом негира вредност народне смеховне културе, изражава презир према карневалском духу:

Jeste, mi poslovicama i takozvanim narodnim mudrostima, pravdamo sve primitivno i glupo što nas satire i čini beznačajnim. Naša kobajagi „zdrava pamet” sitan je i ćiftinski raison 
d'etre, opravdanje beskorisnih žderačkih i pijanačkih bitisanja, odbrana lenjog i zatupelog malograđanina pred svim tajnama, strastima i užasima i lepotama neba i zemlje... (Лукић 1989: 161).

Дугачак је низ доказа продора карневализације у драме о Лази Костићу. Такве су и амбивалентне слике жене, приказ јалове старости, такође заснован на „,narodno-uličnoj, karnevalskoj osnovi” (Бахтин 1978: 261), у драми Panсодија Владимира Б. Поповића. Лик у драми, Симо Матавуљ, опомиње свог пријатеља Лазу Костића на начин како то чини Пантагруел у Трећој књизи Гаргантуа и Пантагруел:

Bolje je i to, nego ovako neizvesno dočekati duboku starost. Zar ne shvataš da će te i ona jednog dana ostaviti? Nikoga nećeš imati, ništa nećeš imati, a ne smeš da se ubiješ! (Popović 2017)

У истој драми постоји и драмска ситуација у којој се Лаза Костић понаша на начин својствен карневалским лудама, кад се „прави луд”, блесав:

(Laza prilazi i ponudi garderobu Lenki. Ona posegne za njom, ali je Laza izmakne. Ovu igru Laza ponovi još nekoliko puta, a onda se Lenka i Vida uhvate za jedan kraj odeće. Vuku odeću. Vrte se u krug. Laza je na jednoj, a Lenka i Vida na drugoj strani.) (Popović 2017).

Наведени и бројни други примери доказ су да су се драмски писци који су писали драме о Лази Костићу ослањали на редуковану карневалску свест. То не би требало да буде никакво изненађење, јер „ро svom vidljivom, konkretno-čulnom karakteru i po prisustvu snažnog elementa igre ove (карневалске, прим. МM) forme, su bliske umetničko-slikovnim formama, naročito pozorišno-predstavljačkim" (Бахтин 1978: 13). Занимањем за озбиљно-смеховне жанрове драмски аутори Ненад Прокић, Радослав Дорић, Велимир Лукић, Владимир Б. Поповић и други, показали су да је карневализација подстицајан модел за аналитички приступ драмским делима о Лази Костићу, јер је њоме могуће обухватити амбивалентан свет са елементима телесности, материјалности, елементарности народног духа, испреплетаним са митским, космичким и универзалним димензијама.

\section{ЛИТЕРАТУРА}

Бахтин 1978: M. Bahtin, Stvaralaštvo Fransoa Rablea i narodna kultura srednjega veka i Renesanse, Beograd: Nolit.

Бергсон 1993: A.Bergson, Smeh. Eseji o značenju komičnog, Beograd: Lapis.

Дорић 1991: R. Dorić, Kamo noći, kamo dani, (rukopis), Sombor: Biblioteka Narodnog pozorišta Sombor, inv. broj 875/26.

Јовановић 2015: S. Jovanović, Karneval i maskerada, (doktorska disertacija), httpwww.arts.bg.ac.rswp-contentuploads201504Smiljka-Jovanovic_doktorska-disertacija.pdf.

Костић 1989: Л. Костић, Дон Кихоту, у: В. Отовић (прир.), Песме, Нови Сад: Матица српска, 300. 
Костић 1989: Л. Костић, Народно глумовање, $y:$ М. Лесковац (прир.), Приповетке, О позоришту и уметности, Нови Сад: Матица српска, 334-350.

Млађеновић 2016: М. Млађеновић, Лик Лазе Костића у драмским делима Радослава Дорића, Театрон, 174-175, 94-103.

Млађеновић 2017: М. Млађеновић, Лице или маска у животу и делу Лазе Костића, Београд: Култура, бр. 155, 28-145.

Поповић 2017: V. B. Popović, Rapsodija. https://www.rastko.rs/drama/savremena/vbpop_rapsodija.html, 31.10.2017.

Прокић 1986: N. Prokić, Homo volans, (rukopis), Novi Sad: Sterijino pozorje, Centar za pozorišnu dokumentaciju, Inv. br. 1065.

Ристивојевић 2009: M. Ristivojević, Bahtin o karnevalu, Etnoantropološki problemi, god. 4, sv. 3, 197-210.

Силард 1984: L. Silard, Karnevalizacija, u: A. Flaker, D. Ugrešić (ur.), Pojmovnik ruske avangarde, svezak 1, Zagreb: Grafički zavod Hrvatske/Zavod za znanost o književnosti Filozofskog fakulteta u Zagrebu, 49-61.

Milivoje V. Mlađenović

\section{CARNEVALISATION IN THE CONCEPTUALISATION OF LAZA KOSTIC} AS A CHARACTER IN PLAYS

(Summary)

Plays in which LazaKostić is a character (particularly Homo volans by Nenad Prokić, Kamo noći, kamo dani by Radoslav Dorić, and to a certain extent Rapsodija by Vladimir.B. Popović, Santa Maria della Salute by Velimir Lukić) as well as the "restoration" of the tragedy Maskim Crnojevic by SlobodanStojanović, originated with the use, the re-shaping, intertextual connecting, destructive and subversive approaches to previous texts, in essence contain the features of carnevalisation as a literary means. The types of carnevalisation in the conceptualisation of Laza Kostić as a character in this paper are analysed, primarily, through grotesque and caricature-like associations. The character of Laza Kostić is portrayed in line with the image of the carnival system in some dramatic sequences. The cosmic, the social and the corporal are shown as an indivisible, living unit. The contours of carnevalisation then appear in the mutual connectedness; in the sublime harmony arising from the sublime chaos, in the desire for the materialisation of non-material sensations, the "erotic cosmism" which rose from the merging with nothingness, the eroticism beaming from the diary of Laza Kostić, etc. The carnival views on the everyday world are identified in the images of his bohemian, theatrical life as well as in reduced forms - sarcasm, irony and satire, the ridicule of the rational citizens and the positivist of the Serbian literary criticism circles aimed towards the romantic "genius". 